\title{
Salinity and cationic nature of irrigation water on castor bean cultivation
}

\author{
Geovani S. de Lima ${ }^{1}$, Reginaldo G. Nobre ${ }^{2}$, Hans R. Gheyi ${ }^{3}$, \\ Lauriane A. dos A. Soares ${ }^{1}$, Carlos A. V. de Azevedo ${ }^{1}$ \& Vera L. A. de Lima ${ }^{1}$
}

${ }^{1}$ Universidade Federal de Campina Grande/Centro de Tecnologia e Recursos Naturais/Unidade Acadêmica de Engenharia Agrícola. Campina Grande, PB. E-mail: geovanisoareslima@gmail.com (Corresponding author) - ORCID: 0000-0001-9960-1858; laurispo.agronomia@gmail.com - ORCID: 00000002-7689-9628; cvieiradeazevedo@gmail.com - ORCID: 0000-0001-7336-1243; antuneslima@gmail.com- ORCID: 0000-0001-7495-6935

${ }^{2}$ Universidade Federal de Campina Grande/Centro de Ciências e Tecnologia Agroalmientar/Unidade Acadêmica de Ciências Agrárias. Pombal, PB. E-mail: rgomesnobre@yahoo.com.br - ORCID: 0000-0002-6429-1527

${ }^{3}$ Universidade Federal do Recôncavo da Bahia/Núcleo de Engenharia de Água e Solo. Cruz das Almas, BA. E-mail: hans@pq.cnpq.br - ORCID: 00000002-1066-0315

\section{Key words:}

Ricinnus communis L. semi-arid region

water shortage

\section{A B S T R A C T}

This study aimed to evaluate the water relations, cell damage percentage and growth of the castor bean cv. 'BRS Energia' as a function of salinity and cationic nature of the water used in irrigation. The experiment was conducted in drainage lysimeters under greenhouse conditions in eutrophic Grey Argisol of sandy loam texture. Six combinations of water salinity and cations were studied $\left(\mathrm{S}_{1}-\mathrm{Control} ; \mathrm{S}_{2}-\mathrm{Na}^{+}, \mathrm{S}_{3}-\mathrm{Ca}^{2+}, \mathrm{S}_{4}-\mathrm{Na}^{+}+\mathrm{Ca}^{2+} ; \mathrm{S}_{5}-\mathrm{K}^{+}\right.$and $\mathrm{S}_{6}-\mathrm{Na}^{+}+\mathrm{Ca}^{2+}+\mathrm{Mg}^{2+}$ ), in a randomized block design with four replicates. In the control $\left(\mathrm{S}_{1}\right)$, plants were irrigated with $0.6 \mathrm{dS} \mathrm{m}{ }^{-1}$ water, whereas the other treatments received $4.5 \mathrm{dS} \mathrm{m}^{-1}$ water, obtained by adding different salts, all in the chloride form. Higher relative water content in the leaf blade of plants irrigated with $\mathrm{K}^{+}$-salinized water associated with leaf succulence are indicative of tolerance of the castor bean cv. 'BRS Energia' to salinity. Saline stress negatively affected castor bean growth, regardless of cationic nature of water. Among the ions studied, 'BRS Energia' castor bean was more sensitive to the presence of sodium in the irrigation water, in terms of both water relations and leaf succulence.

\section{Palavras-chave:}

Ricinnus communis L.

semiárido

escassez de água

\section{Salinidade e natureza catiônica da água de irrigação no cultivo da mamoneira}

\begin{abstract}
R E S U M O
A presente pesquisa propôs avaliar as relações hídricas, o percentual de dano celular e o crescimento da mamoneira cv. BRS Energia em função da salinidade e da natureza catiônica da água utilizada na irrigação. O experimento foi desenvolvido em lisímetros de drenagem em condições de casa de vegetação em Argissolo Acinzentado Eutrófico de textura francoarenosa. Foram estudadas seis combinações de salinidade da água $\left(\mathrm{S}_{1}\right.$ - Testemunha; $\mathrm{S}_{2}-\mathrm{Na}^{+} ; \mathrm{S}_{3}-\mathrm{Ca}^{2+} ; \mathrm{S}_{4}-\mathrm{Na}^{+}+\mathrm{Ca}^{2+} ; \mathrm{S}_{5}-\mathrm{K}^{+} \mathrm{e} \mathrm{S}_{6}-\mathrm{Na}^{+}+\mathrm{Ca}^{2+}+\mathrm{Mg}^{2+}$, no delineamento em blocos casualizados com quatro repetições. Na testemunha $\left(\mathrm{S}_{1}\right)$, as plantas foram irrigadas com água de condutividade elétrica (CEa) de $0,6 \mathrm{dS} \mathrm{m}^{-1}$, enquanto se utilizou nos demais tratamentos água com CEa de $4,5 \mathrm{dS} \mathrm{m}^{-1}$, obtida a partir de diferentes cátions, todos na forma de cloreto. $\mathrm{O}$ maior teor relativo de água no limbo foliar nas plantas irrigadas com água de composição potássica associado à suculência foliar são indicativos de tolerância da mamoneira cv. BRS Energia à salinidade. O estresse salino afetou, de forma negativa, $o$ crescimento da mamoneira, independentemente da natureza catiônica da água. Dentre os íons estudados, a mamoneira foi mais sensível à presença do sódio na água de irrigação, tanto em termos de relações hídricas como para a suculência foliar.
\end{abstract}




\section{INTRODUCTION}

Belonging to the Euphorbiaceae family, castor bean (Ricinus communis L.) is an oilseed crop that stands out in Northeast Brazil due to its characteristics of xerophilism and heliophilism, besides good adaptation to different soil and management conditions. It is a rustic crop, with fast growth, high yield and various possibilities of use for the oil extracted from its seeds (Marinho et al., 2010).

Products and byproducts obtained from the castor bean crop have high socioeconomic value, with applications in the manufacture of nylon fabrics, in the steel industry as cutting oil for lamination, in the industry for the finishing of fine leather, paints and varnishes, perfumery. The oil extracted from the seeds has $90 \%$ ricinoleic acid, which promotes high economic value as lubricant for high-speed engines, being widely used in aviation, whereas in medicine it has been used for its purgative qualities (Silva et al., 2008).

Despite its importance for the semi-arid region of Northeast Brazil, the areas cultivated in this region are subject to agroclimatic variation, in which it is common the occurrence of high temperatures, low rainfall, irregular rainfall distribution and high evapotranspiration rates in most of the year, favoring the scarcity of surface waters. Thus, the irrigation practice is an important measure to guarantee water supply in moments of higher demands (Nobre et al., 2011).

Various studies highlight the castor bean crop as moderately sensitive to salinity (Babita et al., 2010; Nobre et al., 2013; Santos et al., 2013). However, crop tolerance to salinity may vary between species and cultivars of the same species, besides other factors such as type of salt, time of exposure to stress, phenological stage, edaphoclimatic factors and interaction between them (Munns \& Tester, 2008).

In this context, various studies have found negative effects of salinity on castor bean growth and development (Campos et al., 2009; Alves et al., 2012; Nobre et al., 2013; Santos et al., 2013; Lima et al., 2014). Nevertheless, these studies are limited to evaluating only the use of waters with different salinity levels, and new studies become necessary, especially to assess the effects of using waters with different cationic compositions on the castor bean cultivar 'BRS Energia' under semi-arid conditions in Northeast Brazil.

In this context, this study aimed to evaluate the water relations, percentage of cell membrane damage and growth of the castor bean cultivar 'BRS Energia', as a function of salinity and cationic nature of the irrigation water.

\section{Material ANd Methods}

The study was carried out in drainage lysimeters under greenhouse conditions, at the Center of Technology and Natural Resources of the Federal University of Campina Grande (CTRN/UFCG), municipality of Campina Grande-PB, Brazil (7 15’ 18” S; 35 52' 28” W; $550 \mathrm{~m}$ ).

Treatments consisted in six types of salinity $\left(\mathrm{S}_{1}-\right.$ Control; $\mathrm{S}_{2}-\mathrm{Na}^{+} ; \mathrm{S}_{3}-\mathrm{Ca}^{2+} ; \mathrm{S}_{4}-\mathrm{Na}^{+}+\mathrm{Ca}^{2+} ; \mathrm{S}_{5}-\mathrm{K}^{+}$and $\mathrm{S}_{6}-\mathrm{Na}^{+}+\mathrm{Ca}^{2+}$ $\left.+\mathrm{Mg}^{2+}\right)$, in such a way to have equivalent proportions of $1: 1$ for $\mathrm{Na}: \mathrm{Ca}$ in $\mathrm{S}_{4}$ and 7:2:1 for $\mathrm{Na} \mathrm{Ca}: \mathrm{Mg}$ in $\mathrm{S}_{6}$, respectively.
Water with electrical conductivity (ECw) of $0.6 \mathrm{dS} \mathrm{m} \mathrm{m}^{-1}$ was used to irrigate plants in the control treatment $\left(\mathrm{S}_{1}\right)$, whereas the other types of water had ECw of $4.5 \mathrm{dS} \mathrm{m}^{-1}$, prepared by adding compound(s) of different cations, in chloride form. The experiment was set in randomized blocks with six treatments and four replicates, totaling 24 experimental plots.

Plants were grown in drainage lysimeters with capacity for $100 \mathrm{~L}$ (50 cm height, $30 \mathrm{~cm}$ bottom diameter and $33 \mathrm{~cm}$ top diameter) with 2 holes at the bottom to allow drainage, attached to a 4-mm-diameter drain. The tip of the drain inside the lysimeter was involved in nonwoven geotextile (Bidim OP 30).

The lysimeters were filled with a $2 \mathrm{~kg}$ layer of crushed stone ( $\mathrm{n}^{\mathrm{o}}$ zero) followed by $54 \mathrm{~kg}$ of soil material (properly pounded to break up clods and homogenized) and $76 \mathrm{~kg}$ of the same soil mixed with aged bovine manure to achieve $1 \%$ organic matter content, and its quantity was determined based on soil volume.

The soil used in the experiment was collected in the $0-30 \mathrm{~cm}$ layer (A horizon) of a Eutrophic Grey Argisol, from the district of São José da Mata (Campina Grande, PB), and its chemical and physical-hydraulic characteristics were obtained according to the methodologies described by Claessen (1997).

Based on soil analysis data, $\mathrm{pH}$ was corrected by adding $49.25 \mathrm{~g}$ of dolomitic limestone in the soil of each lysimeter ( $130 \mathrm{~kg}$ of soil), quantity required to neutralize $\mathrm{Al}^{3+}$ and increase the contents of $\mathrm{Ca}^{2+}$ and $\mathrm{Mg}^{2+}$ to $70 \%$. After correction, the soil showed the following chemical characteristics: $\mathrm{Ca}^{2+}=1.14 \mathrm{cmol}_{\mathrm{c}} \mathrm{kg}^{-1}$; $\mathrm{Mg}^{2+}=1.36 \mathrm{cmol}_{\mathrm{c}} \mathrm{kg}^{-1} ; \mathrm{Na}^{+}=0.30 \mathrm{cmol}_{\mathrm{c}} \mathrm{kg}^{-1} ; \mathrm{K}^{+}=0.14 \mathrm{cmol}_{\mathrm{c}} \mathrm{kg}^{-1}$; $\mathrm{H}^{+}=0.11 \mathrm{cmol}_{\mathrm{c}} \mathrm{kg}^{-1} ; \mathrm{Al}^{3+}=0 \mathrm{cmol}_{\mathrm{c}} \mathrm{kg}^{-1} ; \mathrm{CEC}=3.05 \mathrm{cmol}_{\mathrm{c}} \mathrm{kg}^{-1}$; Organic matter $=1.08 \mathrm{dag} \mathrm{kg}^{-1} ; \mathrm{P}=47.80 \mathrm{mg} \mathrm{kg}^{-1}$ and $\mathrm{pH}$ in water $(1: 2.5)=6.42$.

Water salinity levels were obtained by dissolving the chloride salt of the respective cations, according to the preestablished treatments in water from the local supply system (Campina Grande, PB). The quantity of the compound was determined based on the equation of Richards (1954), considering the relationship between $\mathrm{ECW}$ and concentration of salts $\left(10^{*}\right.$ mmol $\left._{c} \mathrm{~L}^{-1}=1 \mathrm{dS} \mathrm{m} \mathrm{m}^{-1}\right)$.

Ten seeds of the castor bean cv. 'BRS Energia' were planted in each lysimeter, $2 \mathrm{~cm}$ deep and equidistantly distributed. Ten days after sowing (DAS), thinning was performed to leave only one plant per pot. After sowing, the soil was maintained at field capacity with daily irrigations, and the volume to be applied was determined according to the methodology previously cited by Lima et al. ( 2014).

Based on recommendations of Novais et al. (1991), $40.62 \mathrm{~g}$ of potassium nitrate and $75 \mathrm{~g}$ of monoammonium phosphate, corresponding to 100,150 and $300 \mathrm{mg} \mathrm{kg}^{-1}$ of soil of $\mathrm{N}, \mathrm{K}_{2} \mathrm{O}$ and $\mathrm{P}_{2} \mathrm{O}_{5}$, respectively, were provided in four applications via fertigation, at 10-day intervals, with the first application at 15 DAS. To present probable deficiencies of nutrients, the castor bean plants received $7 \mathrm{~L}$ of a solution containing $2.5 \mathrm{~g} \mathrm{~L}^{-1}$ of Ubyfol [(N (15\%); $\mathrm{P}_{2} \mathrm{O}_{5}$ (15\%); $\mathrm{K}_{2} \mathrm{O}(15 \%) ; \mathrm{Ca}(1 \%) ; \mathrm{Mg}(1.4 \%)$; $\mathrm{S}$ (2.7\%); Zn (0.5\%); B (0.05\%); Fe (0.5\%); Mn (0.05\%); Cu $(0.5 \%)$; Mo $(0.02 \%)]$ sprayed on the leaves, at 30 and 60 DAS.

Effects of salinity and cationic nature of irrigation water on the castor bean $\mathrm{cv}$. 'BRS Energia' were determined at $80 \mathrm{DAS}$ based on the percentage of cell membrane damage $(\% \mathrm{D})$, relative water content (RWC) in the leaf blade, leaf succulence (SUC), 
plant height $(\mathrm{PH})$, stem diameter (SD) and leaf area (LA). The percentage of cell membrane damage was evaluated as recommended by Campos \& Thi (1997). RWC was determined according to Weatherley (1950).

Leaf succulence was determined based on the relationship proposed by Mantovani (1999): (Fresh phytomass - Dry phytomass/Leaf area). Plant height was measured from the base to the apical meristem. Stem diameter was measured $5 \mathrm{~cm}$ above the base of the plant. Leaf area was obtained by measuring the midrib length of all leaves, using the methodology described by Severino et al. (2005).

The obtained data were evaluated through analysis of variance by $\mathrm{F}$ test. When significant, treatment means were compared by Tukey test at 0.05 probability level, using the statistical program Sisvar (Ferreira, 2011). For comparison between treatments, the respective standard error of each mean was calculated. The contrasts were defined as follows: $\hat{\mathrm{Y}}_{1}\left(\mathrm{~S}_{1}\right.$ vs $\left.\mathrm{S}_{2} ; \mathrm{S}_{3} ; \mathrm{S}_{4} ; \mathrm{S}_{5} ; \mathrm{S}_{6}\right) ; \hat{\mathrm{y}}_{2}\left(\mathrm{~S}_{2} \mathrm{vs}_{3}\right) ; \hat{\mathrm{Y}}_{3}\left(\mathrm{~S}_{2} \mathrm{vs}_{6}\right) ; \hat{\mathrm{Y}}_{4}\left(\mathrm{~S}_{2} \mathrm{vs}_{5}\right)$ and $\hat{\mathrm{y}}_{5}\left(\mathrm{~S}_{5}\right.$ vs $\left.\mathrm{S}_{2} ; \mathrm{S}_{3} ; \mathrm{S}_{4} ; \mathrm{S}_{6}\right)$.

\section{Results And Discussion}

According to the analysis of variance summary (Table 1), the cationic composition of the irrigation water had significant effect $(\mathrm{p}<0.01)$ on the percentage of cell membrane damage $(\% \mathrm{D})$, relative water content in the leaf blade (RWC), leaf succulence (SUC), plant height (PH), stem diameter (SD) and leaf area (LA) of the castor bean cv. 'BRS Energia'.
According to the means comparison test (Figure 1A) for the percentage of damage to the cell membrane of the leaf tissue, the use of $\mathrm{K}^{+}$-salinized water $\left(\mathrm{S}_{5}\right)$ in irrigation led to statistically superior values of $\% \mathrm{D}$ in comparison to calcium salt $\left(\mathrm{S}_{3}\right)$. Among the other treatments $\left(\mathrm{S}_{1} ; \mathrm{S}_{2} ; \mathrm{S}_{4} ; \mathrm{S}_{5}\right.$ and $\left.\mathrm{S}_{6}\right)$, castor bean plants irrigated with $\mathrm{S}_{3}$ water deserve attention due to the lower $\% \mathrm{D}$, evidencing lower damages to the leaf tissue membrane.

Based on the contrasts of means obtained for the percentage of damage to leaf tissue membrane (Table 2), significant effect occurred only in the comparison between plants irrigated using waters from the treatments $S_{2}$ vs $S_{3}\left(\hat{y}_{2}\right)$ and $S_{5}$ vs $S_{2} ; S_{3}$; $\mathrm{S}_{4} ; \mathrm{S}_{6}\left(\hat{\mathrm{y}}_{5}\right)$. According to the estimate of the mean, there was an increment of $4.89 \%$ in the mean $\% \mathrm{D}$ of plants irrigated using $\mathrm{S}_{2}$ water, compared with those under $\mathrm{S}_{3}$ water. Comparing $\mathrm{S}_{5}$ vs the other salts $\left(\mathrm{S}_{2} ; \mathrm{S}_{3} ; \mathrm{S}_{4} ; \mathrm{S}_{6}\right)$, it is noted that the \%D obtained in the $\mathrm{S}_{5}$ treatment was $3.89 \%$ higher than that of plants subjected to different cations in the irrigation water.

The lower $\% \mathrm{D}$ observed in plants irrigated using water prepared with $\mathrm{Ca}^{2+}$ demonstrates the lower damages to the membrane integrity of castor bean leaf tissue. According to Mengel \& Kirkby (2000), this occurs because Ca participates in cell membrane integrity, regulation of cell membrane functionality and activation of various enzymatic systems. In addition, the increment in the percentage of cell membrane damage observed in plants irrigated using $\mathrm{K}^{+}$-salinized water $\left(\mathrm{S}_{5}\right)$ may have occurred due to the increase in the amount of reactive oxygen species (superoxides), free radicals and

Table 1. Summary of analysis of variance for percentage of cell membrane damage (\%D), relative water content (RWC) in the leaf blade, leaf succulence (SUC), plant height (PH), stem diameter (SD) and leaf area (LA) of the castor bean cV. 'BRS Energia' irrigated using water with different cationic compositions, at 80 days after sowing

\begin{tabular}{|c|c|c|c|c|c|c|c|}
\hline \multirow{2}{*}{ SV/Contrasts\# } & \multirow{2}{*}{ DF } & \multicolumn{6}{|c|}{ Mean squares } \\
\hline & & \%D & RWC & SUC & $\mathrm{PH}$ & SD & LA \\
\hline Blocks & 3 & $0.27^{\mathrm{ns}}$ & $23.26^{\mathrm{ns}}$ & $0.00005^{\mathrm{ns}}$ & $14.11^{\text {ns }}$ & $7.71^{\mathrm{ns}}$ & $637005.56^{\text {ns }}$ \\
\hline Water cationic composition & (5) & $22.82^{* *}$ & $675.14^{\star *}$ & $0.001^{\star \star}$ & $487.24^{\star \star}$ & $47.06^{\star *}$ & $84121507.71^{\star *}$ \\
\hline$\hat{\mathrm{y}}_{1}$ & 1 & $0.007^{\mathrm{ns}}$ & $1197.00^{* *}$ & $0.004^{* *}$ & $2200.77^{\star \star}$ & $200.61^{\star \star}$ & $412616054.56^{*}$ \\
\hline$\hat{\mathrm{y}}_{2}$ & 1 & $47.96^{*}$ & $1152.00^{* *}$ & $0.001^{* *}$ & $0.14^{\mathrm{ns}}$ & $0.08^{\text {ns }}$ & 32701.09ns \\
\hline$\hat{\mathrm{y}}_{3}$ & 1 & $1.42^{\mathrm{ns}}$ & $351.12^{\star}$ & $0.0001^{*}$ & $37.77^{\text {ns }}$ & $0.14^{\mathrm{ns}}$ & $1037113.22^{\text {ns }}$ \\
\hline$\hat{\mathrm{y}}_{4}$ & 1 & $12.02^{\text {ns }}$ & $1830.12^{\star \star}$ & $0.004^{\star *}$ & $166.37^{*}$ & $25.22^{*}$ & $6174110.29^{*}$ \\
\hline$\hat{y}_{5}$ & 1 & $48.44^{*}$ & $775.01^{*}$ & $0.003^{\star *}$ & $175.97^{\star}$ & $31.90^{\star}$ & $6796829.74^{*}$ \\
\hline Residual & 15 & 4.93 & 35.89 & 0.00002 & 14.99 & 2.79 & 440766.11 \\
\hline CV (\%) & & 13.57 & 7.74 & 9.96 & 6.76 & 9.69 & 15.16 \\
\hline
\end{tabular}

${ }^{*} \hat{y}_{1}\left(\mathrm{~S}_{1}\right.$ vs $\left.\mathrm{S}_{2} ; \mathrm{S}_{3} ; \mathrm{S}_{4} ; \mathrm{S}_{5} ; \mathrm{S}_{6}\right) ; \hat{y}_{2}\left(\mathrm{~S}_{2}\right.$ vs $\left.\mathrm{S}_{3}\right) ; \hat{y}_{3}\left(\mathrm{~S}_{2}\right.$ vs $\left.\mathrm{S}_{6}\right) ; \hat{y}_{4}\left(\mathrm{~S}_{2}\right.$ vs $\left.\mathrm{S}_{5}\right) ; \hat{\mathrm{y}}_{5}\left(\mathrm{~S}_{5}\right.$ vs $\left.\mathrm{S}_{2} ; \mathrm{S}_{3} ; \mathrm{S}_{4} ; \mathrm{S}_{6}\right) ;$ Subscripts $1,2,3,4,5$ and 6 represent the waters $\mathrm{S}_{1}=\mathrm{Control} ; \mathrm{S}_{2}=\mathrm{Na}^{+} ; \mathrm{S}_{3}=\mathrm{Ca}^{2+}$ $\mathrm{S}_{4}=\mathrm{Na}^{+}+\mathrm{Ca}^{2+} ; \mathrm{S}_{5}=\mathrm{K}^{+} ; \mathrm{S}_{6}=\mathrm{Na}^{+}+\mathrm{Ca}^{2+}+\mathrm{Mg}^{2+} ; \mathrm{SV}$ - Source of variation; DF - Degree of freedom; CV - Coefficient of variation; $\left({ }^{*}\right)$ and $\left({ }^{*}\right)$ Significant at 0.05 and 0.01 probability levels, respectively; (ns) Not significant
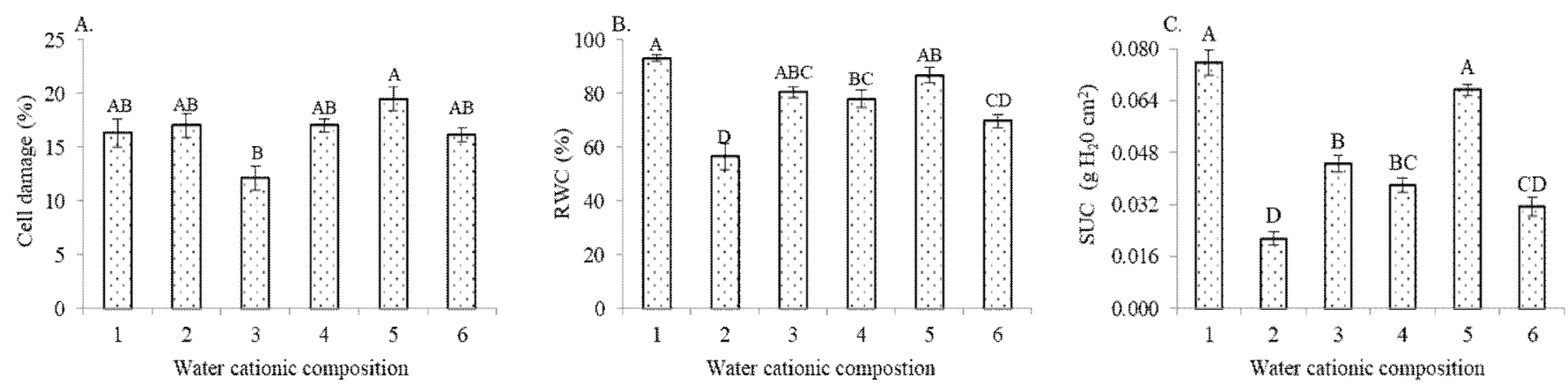

$1=$ Control; $2=\mathrm{Na}^{+} ; 3=\mathrm{Ca}^{2+} ; 4=\mathrm{Na}^{+}+\mathrm{Ca}^{2+} ; 5=\mathrm{K}^{+} ; 6=\mathrm{Na}^{+}+\mathrm{Ca}^{2+}+\mathrm{Mg}^{2+}$

Bars represent standard error of the mean $(n=4)$. Means followed by different letters differ by Tukey test $(p<0.05)$

Figure 1. Percentage of damage to leaf tissue membrane - \%D (A), relative water content (RWC) in the leaf blade $(B)$ and leaf succulence - SVC (C) of the castor bean CV. 'BRS Energia' under different cationic composition of the irrigation water, at 80 days after sowing 
Table 2. Estimate of the mean for percentage of cell membrane damage $(\% \mathrm{D})$, relative water content (RWC) in the leaf blade, leaf succulence (SUC), plant height (PH), stem diameter (SD) and leaf area (LA) of the castor bean cv. 'BRS Energia' irrigated using waters of different cationic compositions, at 80 days after sowing

\begin{tabular}{|c|c|c|c|c|c|c|}
\hline \multirow[b]{2}{*}{ Contrasts" } & \multicolumn{6}{|c|}{ Estimate of mean } \\
\hline & $\% D$ & $\begin{array}{l}\text { RWC } \\
(\%)\end{array}$ & $\begin{array}{c}\text { SUC } \\
\left(\mathrm{g} \mathrm{H}_{2} \mathrm{O} \mathrm{cm}^{2}\right)\end{array}$ & $\begin{array}{l}\mathrm{PH} \\
\text { (cm) }\end{array}$ & $\begin{array}{c}\text { SD } \\
(\mathrm{mm})\end{array}$ & $\begin{array}{c}\text { LA } \\
\left(\mathrm{cm}^{2}\right)\end{array}$ \\
\hline$\hat{y}_{1}$ & ns & 18.95 & 0.03 & 25.69 & 7.75 & 11125.86 \\
\hline$\hat{\mathrm{Y}}_{2}$ & 4.89 & -24.00 & -0.02 & ns & ns & ns \\
\hline$\hat{\mathrm{Y}}_{3}$ & $\mathrm{~ns}$ & -13.25 & -0.009 & $\mathrm{~ns}$ & $\mathrm{~ns}$ & ns \\
\hline$\hat{\mathrm{y}}_{4}$ & $\mathrm{~ns}$ & -30.25 & -0.04 & -9.12 & -3.55 & -1757.00 \\
\hline$\hat{\mathrm{y}}_{5}$ & 3.89 & 15.56 & 0.03 & 7.41 & 3.15 & 1457.39 \\
\hline
\end{tabular}

${ }^{\#} \hat{\mathrm{y}}_{1}\left(\mathrm{~S}_{1}\right.$ vs $\left.\mathrm{S}_{2} ; \mathrm{S}_{3} ; \mathrm{S}_{4} ; \mathrm{S}_{5} ; \mathrm{S}_{6}\right) ; \hat{\mathrm{y}}_{2}\left(\mathrm{~S}_{2}\right.$ vs $\left.\mathrm{S}_{3}\right) ; \hat{y}_{3}\left(\mathrm{~S}_{2}\right.$ vs $\left._{6}\right) ; \hat{\mathrm{y}}_{4}\left(\mathrm{~S}_{2}\right.$ vs $\left.\mathrm{S}_{5}\right) ; \hat{\mathrm{y}}_{5}\left(\mathrm{~S}_{5}\right.$ vs $\left.\mathrm{S}_{2} ; \mathrm{S}_{3} ; \mathrm{S}_{4} ; \mathrm{S}_{6}\right) ;$ Subscripts $1,2,3,4,5$ and 6 represent the waters $\mathrm{S}_{1}=$ Control; $\mathrm{S}_{2}=\mathrm{Na}^{+} ; \mathrm{S}_{3}=\mathrm{Ca}^{2+}$ $\mathrm{S}_{4}=\mathrm{Na}^{+}+\mathrm{Ca}^{2+} ; \mathrm{S}_{5}=\mathrm{K}^{+} ; \mathrm{S}_{6}=\mathrm{Na}^{+}+\mathrm{Ca}^{2+}+\mathrm{Mg}^{2+}$, respectively

enzymes, which lead to membrane rupture and increase permeability and, often, to irreversible damages in the organelles and molecules present inside the cells (Alonso et al., 1997).

According to the comparison of means test for relative water content in the leaf blade (Figure 1B), 'BRS Energia' castor bean plants irrigated with $\mathrm{Na}^{+}$-salinized water $\left(\mathrm{S}_{2}\right)$ differed statistically from those subjected to the treatments $S_{1}, S_{3}, S_{4}$ and $\mathrm{S}_{5}$. On the other hand, only plants subjected to irrigation using water prepared with $\mathrm{Na}^{+}\left(\mathrm{S}_{2}, \mathrm{~S}_{4}\right.$ and $\left.\mathrm{S}_{6}\right)$ significantly stand out from the control treatment $\left(\mathrm{S}_{1}\right)$, and lowest RWC (56.50\%) was found in plants irrigated with $\mathrm{NaCl}\left(\mathrm{S}_{2}\right)$. In contrast, plants irrigated using $\mathrm{Ca}^{2+}$ water $\left(\mathrm{S}_{3}\right)$ and $\mathrm{K}^{+}$water $\left(\mathrm{S}_{5}\right)$ did not differ from those subjected to the lowest $\mathrm{ECw}$ level-control $\left(\mathrm{S}_{1}\right)$.

Table 2 shows the summary for the contrasts of means referring to RWC in the leaf blade. Based on the contrasts of means referring to the RWC, plants irrigated with $\mathrm{ECW}=0.6 \mathrm{dS} \mathrm{m}^{-1}$ $\left(\mathrm{S}_{1}\right)$ significantly differed from those under $\mathrm{ECw}=4.5 \mathrm{dS} \mathrm{m}^{-1}$ $\left(\mathrm{S}_{2} ; \mathrm{S}_{3} ; \mathrm{S}_{4} ; \mathrm{S}_{5} ; \mathrm{S}_{6}\right)$. According to the estimate of mean, in plants irrigated using $0.6 \mathrm{dS} \mathrm{m}^{-1}$ water, RWC increased by $18.95 \%$ compared with those subjected to $\mathrm{ECW}=4.5 \mathrm{dS} \mathrm{m}^{-1}$.

Comparing the data of treatments $\mathrm{S}_{2}$ vs $\mathrm{S}_{3}$ (Table 2), when $\mathrm{Na}^{+}$-salinized water was used in irrigation, RWC was $24 \%$ lower in the plants, in comparison to $\mathrm{S}_{3}$. On the other hand, plants subjected to irrigation with $\mathrm{Na}^{+}$-salinized water $\left(\mathrm{S}_{2}\right)$ showed reduction of $13.25 \%$ in RWC, compared with those irrigated with $\mathrm{S}_{6}\left(\mathrm{Na}^{+}+\mathrm{Ca}^{2+}+\mathrm{Mg}^{2+}\right)$. For the treatments $\mathrm{S}_{2}$ vs $\mathrm{S}_{5}$, when $\mathrm{Na}^{+}$-salinized water was applied, plants showed a decrease of $30.25 \%$ in RWC, compared with those under the $\mathrm{S}_{5}$ treatment $\left(\mathrm{K}^{+}\right)$.

For leaf succulence (SUC), according to the means comparison test (Figure 1C), in the treatment that used lowsalinity water (control) and $\mathrm{K}^{+}$-salinized water $\left(\mathrm{S}_{5}\right)$, SUC was statistically higher compared with plants irrigated using water prepared with the other salts $\left(\mathrm{S}_{2} ; \mathrm{S}_{3} ; \mathrm{S}_{4}\right.$ and $\left.\mathrm{S}_{6}\right)$. Nonetheless, castor bean plants irrigated with $\mathrm{Ca}^{2+}$-salinized water were statistically different from those under salinity of the water prepared with $\mathrm{Na}^{+}\left(\mathrm{S}_{2}\right)$ and $\mathrm{Na}^{+}+\mathrm{Ca}^{2+}+\mathrm{Mg}^{2+}\left(\mathrm{S}_{6}\right)$.

Based on the superiority of SUC data in the $\mathrm{S}_{5}$ treatment, compared with the other types of salts $\left(\mathrm{S}_{2} ; \mathrm{S}_{3} ; \mathrm{S}_{4}\right.$ and $\left.\mathrm{S}_{6}\right)$, when $\mathrm{K}^{+}$-salinized water was used in irrigation, 'BRS Energia' castor bean plants experienced lower deleterious effect caused by water salinity. Silva et al. (2009), evaluating jatropha under salt stress conditions $\left(0,25,50,75\right.$ and $100 \mathrm{mmol}_{c} \mathrm{~L}^{-1}$ of $\left.\mathrm{NaCl}\right)$, also found increments in leaf succulence. These authors also pointed out that such increment in SUC played an effective role in plant osmotic adjustment, a fact observed in the present study in plants irrigated using water prepared with $\mathrm{K}^{+}$.

The analysis of the contrasts between means for SUC (Table 2) shows a significant difference for all contrasts and, based on the estimate of mean, castor bean plants irrigated with water of lowest ECw $\left(0.6 \mathrm{dS} \mathrm{m}^{-1}\right)$ increased SUC by $0.03 \mathrm{~g} \mathrm{H}_{2} \mathrm{O} \mathrm{cm}^{2}$, compared with those irrigated with $\mathrm{ECw}=4.5 \mathrm{dS} \mathrm{m}^{-1}\left(\mathrm{~S}_{2}\right.$; $\mathrm{S}_{3} ; \mathrm{S}_{4} ; \mathrm{S}_{5}$ and $\mathrm{S}_{6}$ ). According to Table 2, plants irrigated with $\mathrm{Na}^{+}$-salinized water $\left(\mathrm{S}_{2}\right)$ showed reduction of $0.02 \mathrm{~g} \mathrm{H}_{2} \mathrm{O} \mathrm{cm}$ in SUC, compared with those irrigated with the $\mathrm{S}_{3}$ treatment. Based on the means obtained in the different treatments $\left(S_{2}\right.$ vs $S_{6} ; S_{2}$ vs $S_{5} ; S_{5}$ vs $S_{2} ; S_{3} ; S_{4} ; S_{6}$ ), plants irrigated with $\mathrm{K}^{+}$salinized water $\left(\mathrm{S}_{5}\right)$ showed statistically superior SUC values in comparison to those under the other types of salts.

Increased SUC in plants grown using $\mathrm{K}^{+}$-salinized water may be an indication that osmotic adjustment occurred in stressed plants (Silva et al., 2009), which is considered as important because succulence is a parameter that allows to regulate the concentration of salts in the leaf tissues and directly depends on absorption, transport and accumulation of ions in the leaf tissues, possibly contributing to reducing the effect of salts on plant growth (Trindade et al., 2006). Hence, the saline stress caused by the high $\mathrm{K}^{+}$concentrations in the irrigation water possibly had a negative effect on the hydration level of the leaf tissues.

The comparison of means test for plant height $(\mathrm{PH})$ (Figure 2A) shows that castor bean plants cultivated under irrigation with low-salinity water $\left(\mathrm{S}_{1}\right)$ grew more in $\mathrm{PH}$, significantly differing from those irrigated with the other types of water, $\mathrm{ECw}=4.5 \mathrm{dS} \mathrm{m}{ }^{-1}$, containing $\mathrm{Na}^{+}\left(\mathrm{S}_{2}\right), \mathrm{Ca}^{2+}\left(\mathrm{S}_{3}\right), \mathrm{Na}^{+}+\mathrm{Ca}^{2+}$ $\left(\mathrm{S}_{4}\right), \mathrm{K}^{+}\left(\mathrm{S}_{5}\right)$ and $\mathrm{Na}^{+}+\mathrm{Ca}^{2+}+\mathrm{Mg}^{2+}\left(\mathrm{S}_{6}\right)$. Additionally, in the comparison of means obtained in the different treatments (Figure 2A), plants subjected to irrigation with $\mathrm{K}^{+}$-salinized water $\left(\mathrm{S}_{5}\right)$ were statistically different from those irrigated with $\mathrm{S}_{2}$ and $\mathrm{S}_{3}$, but were similar to those irrigated with $\mathrm{S}_{4}$ and $\mathrm{S}_{6}$.

For stem diameter (Figure $2 \mathrm{~B}$ ), except in the control $\left(\mathrm{S}_{1}\right)$, there were no significant differences between the different types of irrigation water salinity. In $S_{1}$, mean SD was equal to $23.71 \mathrm{~mm}$, while the other treatments showed an average SD of $15.96 \mathrm{~mm}$ (32.68\% lower). However, it is important to point out that plants irrigated with $\mathrm{S}_{5}$ water showed less accentuated reductions, in comparison to the other types of salts. This fact must be associated with the functions of $K$, because this macronutrient participates in the maintenance of ionic balance and turgor of the cells, by controlling stomatal opening and closure (Gurgel et al., 2010). 

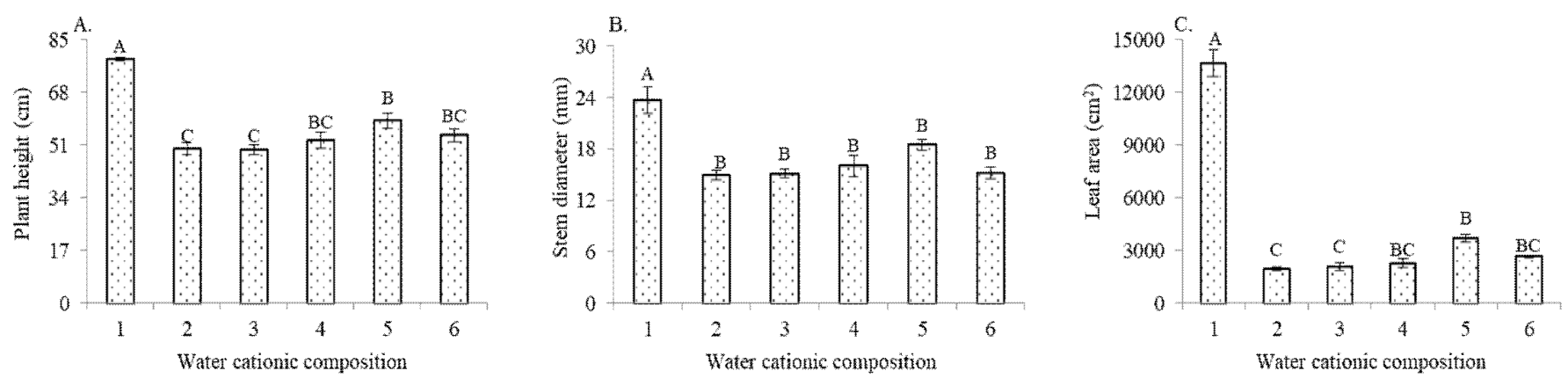

1- Control; $2=\mathrm{Na}^{+} ; 3=\mathrm{Ca}^{2+} ; 4=\mathrm{Na}^{+}+\mathrm{Ca}^{2+} ; 5=\mathrm{K}^{+} ; 6=\mathrm{Na}^{+}+\mathrm{Ca}^{2+}+\mathrm{Mg}^{2+}$

Bars represent the standard error of the mean $(n=4)$. Means with different letters differ by Tukey test $(p<0.05)$

Figure 2. Plant height (A), stem diameter (B) and leaf area (C) of 'BRS Energia' castor bean under different cationic composition of irrigation water, at 80 days after sowing

As observed for PH (Figure 2A), castor bean leaf area (LA) was significantly superior in plants subjected to irrigation using low-salinity water $\left(\mathrm{S}_{1}\right)$, with mean value of 13651.63 $\mathrm{cm}^{2}$, statistically differing from the other treatments $\left(\mathrm{S}_{2} ; \mathrm{S}_{3}\right.$; $\mathrm{S}_{4} ; \mathrm{S}_{5}$ and $\mathrm{S}_{6}$ ), which showed $81.4 \%$ lower LA (on average $2525.76 \mathrm{~cm}^{2}$ ). As shown in Figure 2C, the LA of plants using $\mathrm{K}^{+}$-salinized water $\left(\mathrm{S}_{5}\right)$ was significantly superior to those of the other treatments with $\mathrm{Na}^{+}\left(\mathrm{S}_{2}\right)$ and $\mathrm{Ca}^{2+}\left(\mathrm{S}_{3}\right)$, which did not differ from $\mathrm{Na}^{+}+\mathrm{Ca}^{2+}\left(\mathrm{S}_{4}\right)$ and $\mathrm{Na}^{+}+\mathrm{Ca}^{2+}+\mathrm{Mg}^{2+}\left(\mathrm{S}_{6}\right)$.

Based on the contrasts of means shown in Table 2, plant height, stem diameter and leaf area of castor bean plants irrigated with $\mathrm{ECw}=0.6 \mathrm{dS} \mathrm{m} \mathrm{m}^{-1}\left(\mathrm{~S}_{1}\right)$ significantly varied in comparison to those under $\mathrm{ECw}=4.5 \mathrm{dS} \mathrm{m}{ }^{-1}\left(\mathrm{~S}_{2} ; \mathrm{S}_{3} ; \mathrm{S}_{4} ; \mathrm{S}_{5}\right.$ and $\mathrm{S}_{6}$ ) and, based on the estimate of mean (Table 2 ), the values of PH, SD and LA in the plants subjected to these treatments were $25.69 \mathrm{~cm}, 7.75 \mathrm{~mm}$ and $11125.86 \mathrm{~cm}^{2}$ lower, respectively. The reduction in castor bean growth, evidenced by the decrease in plant height, stem diameter and leaf area, due to the use of waters with different ionic compositions, may also be related to the genetics of the plant, osmotically adjusting in the initial development stage, allocating greater amount of energy for the accumulation of sugars, organic acids and ions in the vacuole, energy that could be used for plant growth (Santos et al., 2012).

A joint analysis of the results obtained (\%D, RWC, SUC, $\mathrm{PH}, \mathrm{SD}$ and LA) reveals that the greater growth of castor bean plants in the treatments $S_{1}$ and $S_{5}$ may be related to the higher relative water content in the leaf blade, which led to high succulence in the leaf tissues, suggesting a strategy of osmotic adjustment by the crop. In this case, greater growth of the castor bean crop may also be related to cell wall extensibility, which is determined by the positive turgor pressure inside the cells. The results obtained in the present study agree with those of Lima et al. (2014), who found that increased irrigation water salinity (ECw varying from 0.3 to $3.9 \mathrm{dS} \mathrm{m}^{-1}$ ) significantly reduced plant height, stem diameter and leaf area of 'BRS Energia' castor bean plants, at 30,60 and 120 DAS.

Based on the contrasts $S_{2}$ vs $S_{3}$ and $S_{2}$ vs $S_{6}$, there was no significant influence $(\mathrm{p}>0.05)$ on $\mathrm{PH}, \mathrm{SD}$ and LA. It can be seen from the mean estimation data (Table 2) that the plants irrigated with sodium $\left(\mathrm{S}_{2}\right)$ water had $\mathrm{PH}, \mathrm{SD}$ and LA, respectively $9.12 \mathrm{~cm}, 3.55 \mathrm{~mm}$ and $1757.00 \mathrm{~cm}^{2}$ less in comparison to those receiving water prepared with potassium $\left(\mathrm{S}_{5}\right)$. While comparing the castor bean plants irrigated with water of potassium ion composition in relation to the other cations $\left(\mathrm{S}_{2}, \mathrm{~S}_{3}, \mathrm{~S}_{4}\right.$ and $\left.\mathrm{S}_{6}\right)$, there was superiority in $\mathrm{PH}, \mathrm{SD}$ and
LA, with a mean value of $7.41 \mathrm{~cm}, 3.15 \mathrm{~mm}$ and $1457.39 \mathrm{~cm}^{2}$, respectively.

\section{Conclusions}

1. Higher relative water content in the leaf blade of plants irrigated using $\mathrm{K}^{+}$-salinized water associated with leaf succulence are indicative of tolerance to salinity by the castor bean cv. 'BRS Energia'.

2. Salt stress negatively affects castor bean growth, regardless of the cationic nature of the water.

3. The castor bean cv. 'BRS Energia' is more sensitive to the presence of sodium in the irrigation water, in terms of both water relations and leaf succulence.

\section{Literature Cited}

Alonso, A.; Queiroz, C. S.; Magalhães, A. C. Chilling stress leads to increased cell membrane rigidity in roots of coffee (Coffea arabica L.) seedlings. Biochimica et Biophysica Acta, v.1323, p.75-84, 1997. https://doi.org/10.1016/S0005-2736(96)00177-0

Alves, A. N.; Gheyi, H. R.; Uyeda, C. A.; Soares, F. A. L.; Nobre, R. G.; Cardoso, J. A. F. Uso de águas salinas e adubação nitrogenada no cultivo da mamoneira BRS-Energia. Revista Brasileira de Agricultura Irrigada, v.6, p.151-163, 2012. https://doi.org/10.7127/ rbai.v6n200218

Babita, M.; Maheswari, M.; Rao, L. M.; Shanker, A. K.; Rao, D. G. Osmotic adjustment, drought tolerance and yield in castor (Ricinus communis L.) hybrids. Environmental and Experimental Botany, v.69, p.243-249, 2010. https://doi.org/10.1016/j. envexpbot.2010.05.006

Campos, P. S.; Thi, A. T. P. Effects of an abscisic acid pretreatment on membrane leakage and lipid composition of Vigna unguiculata leaf discs subject to ormotic stress. Plant Science, v.130, p.11-18, 1997. https://doi.org/10.1016/S0168-9452(97)00199-4

Campos, V. B. Cavalcante, L. F.; Rodolfo Júnior. F.; Sousa, G. G.; Mota, J. K. Crescimento inicial da mamoneira em resposta à salinidade e biofertilizante bovino. Magistra, v.21, p.41-47, 2009.

Claessen, M. E. C. Manual de métodos de análise de solo. 2.ed. rev. atual. Rio de Janeiro: EMBRAPA-CNPS, 1997.212p. EMBRAPACNPS. Documentos, 1

Ferreira, D. F. Sisvar: A computer statistical analysis system. Ciência e Agrotecnologia, v.35, p.1039-1042, 2011. https://doi.org/10.1590/ S1413-70542011000600001 
Gurgel, M. T.; Uyeda, C. A.; Gheyi, H. R.; Oliveira, F. H. T. de; Fernandes, P. D.; Silva, F. V. da. Crescimento de meloeiro sob estresse salino e doses de potássio. Revista Brasileira de Engenharia Agrícola e Ambiental, v.14, p.3-10, 2010. https://doi. org/10.1590/S1415-43662010000100001

Lima, G. S. de; Nobre, R. G.; Gheyi, H. R.; Soares, L. A. dos A.; Silva, S. S. da. Respostas morfofisiológicas da mamoneira, em função da salinidade da água de irrigação e adubação nitrogenada. Irriga, v.19, p.130-136, 2014. https://doi.org/10.15809/irriga.2014v19n1p130

Mantovani, A. A method to improve leaf succulence quantification. Brazilian Archives of Biology and Technology, v.42, p.9-14, 1999. https://doi.org/10.1590/S1516-89131999000100002

Marinho, A. B.; Moreira, L. G.; Viana, T. V. de A.; Albuquerque, A. H. P.; Oliveira, C. W.; Azevedo, B. M. de. Influência da fertirrigação da nitrogenada na produtividade da cultura da mamoneira. Revista Brasileira de Agricultura Irrigada, v.4, p.31-42, 2010. https://doi. org/10.7127/rbai.v4n100024

Mengel, K.; Kirkby, E. A. Princípios de nutrición vegetal. Basel: International Potash Institute, 2000. 692p.

Munns, R.; Tester, M. Mechanisms of salinity tolerance. Annual Review of Plant Biology, v.59, p.651-681, 2008. https://doi. org/10.1146/annurev.arplant.59.032607.092911

Nobre, R. G.; Gheyi, H. R.; Soares, F. A. L.; Cardoso, J. A. F. Produção de girassol sob estresse salino e adubação nitrogenada. Revista Brasileira de Ciência do Solo, v.35, p.929-937, 2011. https://doi. org/10.1590/S0100-06832011000300027

Nobre, R. G.; Lima, G. S. de; Gheyi, H. R.; Lourenço, G. da S.; Soares, L. A. dos A. Emergência, crescimento e produção da mamoneira sob estresse salino e adubação nitrogenada. Revista Ciência Agronômica, v.44, p.76-85, 2013. https://doi.org/10.1590/S180666902013000100010

Novais, R. F.; Neves, J. C. L.; Barros, N. F. Ensaio em ambiente controlado. In: Oliveira, A. J. (ed.). Métodos de pesquisa em fertilidade do solo. Brasília: EMBRAPA-SEA. 1991. p.189-253.
Richards, L. A. Diagnosis and improvement of saline and alkali soils. Washington: U.S, Department of Agriculture, 1954. 160p.

Santos, D. B. dos.; Ferreira, P. A.; Oliveira, F. G. de.; Batista, R. O.; Costa, A. C.; Cano, M. A. O. Produção e parâmetros fisiológicos do amendoim em função do estresse salino. Idesia, v.30, p.69-74, 2012. https://doi.org/10.4067/S0718-34292012000200009

Santos, J. B. dos; Santos, D. B. dos; Azevedo, C. A. V. de; Rebequi, A. M.; Cavalcante, L. F.; Cavalcante, I. H. L. Comportamento morfofisiológico da mamoneira BRS energia submetida à irrigação com água salina. Revista Brasileira de Engenharia Agrícola e Ambiental, v.17, p.145-1522, 2013. https://doi.org/10.1590/S141543662013000200005

Severino, L. S.; Vale, L. S.; Cardoso, G. D.; Beltrão, N. E. de M.; Santos, J. W. dos. Método para determinação da área foliar da mamoneira. Campina Grande: EMBRAPA-CNPA, 2005. 20p. Boletim de Pesquisa e Desenvolvimento, 55.

Silva, E. N. da; Silveira, J. A. G.; Rodrigues, C. R. F.; Lima, C. S. de; Viégas, R. A. Contribuição de solutos orgânicos e inorgânicos no ajustamento osmótico de pinhão-manso submetido à salinidade. Pesquisa Agropecuária Brasileira, v.44, p.437-445, 2009. https:// doi.org/10.1590/S0100-204X2009000500002

Silva, S. M. S.; Alves, A. N.; Gheyi, H. R.; Beltrão, N. E. de M.; Severino, L. S.; Soares, F. A. L. Desenvolvimento e produção de duas cultivares de mamoneira sob estresse salino. Revista Brasileira de Engenharia Agrícola e Ambiental, v.12, p.335-342, 2008. https:// doi.org/10.1590/S1415-43662008000400001

Trindade, A. R.; Lacerda, C. F. de; Gomes Filho, E.; Prisco, J. T.; Bezerra, M. A. Influência do acúmulo e distribuição de íons sobre a aclimatação de plantas de sorgo e feijão-de-corda, ao estresse salino. Revista Brasileira de Engenharia Agrícola e Ambiental, v.10, p.804810, 2006. https://doi.org/10.1590/S1415-43662006000400004

Weatherley, P. E. Studies in the water relations of the cotton plant. I The field measurements of water deficits in leaves. New Phytologist, v.49, p.81-97, 1950. https://doi.org/10.1111/j.1469-8137.1950. tb05146.x 